Review

\title{
Trophic Actions of Bone Marrow-Derived Mesenchymal Stromal Cells for Muscle Repair/Regeneration
}

\author{
Chiara Sassoli, Sandra Zecchi-Orlandini and Lucia Formigli * \\ Department of Anatomy, Histology and Forensic Medicine, University of Florence, Largo Brambilla 3, \\ Florence 50134, Italy; E-Mails: csassoli@unifi.it (C.S.); zecchi@unifi.it (S.Z.-O.) \\ * Author to whom correspondence should be addressed; E-Mail: formigli@unifi.it; \\ Tel.: +39-055-427-1809; Fax: +39-055-437-9500.
}

Received: 27 August 2012; in revised form: 28 September 2012 / Accepted: 9 October 2012 / Published: 17 October 2012

\begin{abstract}
Bone marrow-derived mesenchymal stromal cells (BM-MSCs) represent the leading candidate cell in tissue engineering and regenerative medicine. These cells can be easily isolated, expanded in vitro and are capable of providing significant functional benefits after implantation in the damaged muscle tissues. Despite their plasticity, the participation of BM-MSCs to new muscle fiber formation is controversial; in fact, emerging evidence indicates that their therapeutic effects occur without signs of long-term tissue engraftment and involve the paracrine secretion of cytokines and growth factors with multiple effects on the injured tissue, including modulation of inflammation and immune reaction, positive extracellular matrix (ECM) remodeling, angiogenesis and protection from apoptosis. Recently, a new role for BM-MSCs in the stimulation of muscle progenitor cells proliferation has been demonstrated, suggesting the potential ability of these cells to influence the fate of local stem cells and augment the endogenous mechanisms of repair/regeneration in the damaged tissues.
\end{abstract}

Keywords: cell-based therapy; cell proliferation; mesenchymal stromal cells (MSCs); muscle repair/regeneration; myogenic progenitors; paracrine factors 


\section{Introduction}

Skeletal and cardiac muscles have received much attention in the last years with respect to their regenerative capacities. It is well known that adult skeletal muscle can efficiently undergo repair/regeneration in response to trauma or degenerative diseases due to the activity of a resident population of muscle progenitors, namely satellite cells [1]. These mononucleated cells are localized underneath the basal lamina of each muscle fiber closely juxtaposed to the sarcolemma, within special niches. Here, these cells lie in a dormant state and start to proliferate and differentiate in response to signals emanating from the damaged fibers and infiltrating inflammatory cells in order to form new myofibers within a few days [2-6]. Unfortunately, satellite cells are relatively scarce within the skeletal muscle tissue, representing about $1 \%-5 \%$ of the total muscle nuclei and, in the case of severe muscle damage, they might not be recruited in a sufficient amount at the site of tissue damage. Moreover, their capacity to accomplish the myogenic program is highly compromised by the induction of the inflammatory response and the excessive fibroblast proliferation and collagen fiber deposition [7-9]. Recently, a small population of resident stem/myogenic progenitors (cardiac stem cells, CSCs) have also been identified in the adult heart of mammals including humans, questioning the traditional paradigm of the myocardium as a post-mitotic terminally differentiated tissue [10-14]. These cells are mainly localized into sub-epicardial clusters in the atria, in the ventricular base through the midregion and in the apex [10,11] However, differently from satellite cells, resident CSCs are mainly involved in the maintenance of cardiac tissue homeostasis [15-17], showing a limited regenerative potential [18-21]. Many researchers have thus been devoted to the development of therapeutic strategies for the treatment of degenerative muscle diseases; among them, the stem cell-based therapy is emerging as one of the most promising tools in the field of regenerative medicine [6,20,22-27]. The most obvious candidate cells to be transplanted for skeletal muscle regeneration are the satellite cells, whose therapeutic potency has been demonstrated in experimental models of human dystrophy and skeletal muscle injury [22,28,29]. However, their use for regenerative purposes is hindered by several criticisms including: (i) the high heterogeneity of this cell population [30]; (ii) the loss of their myogenic potential upon isolation and in vitro expansion [29]; (iii) the predetermination dependent from the source (slow versus fast, head versus limb muscles) of skeletal muscle fibers [31,32]; (iv) the scarce cell survival in the host tissue [33]; and, (v) the inability to cross the blood vessel wall, restricting their use to the local injection [23]. The therapeutic application of CSCs in the injured myocardium has also some limitations and concerns substantially related to the absence of a full understanding of the biological and immunophenotypical features of these cells and to the difficulties of their culture expansion and implantation [12,34-39]. These hurdles have shifted the attention of many researchers in the field of cell-based therapy to other stem cell types, in particular to adult bone marrow-derived mesenchymal stromal cells (BM-MSCs) for the treatment of the damaged muscle. These cells, in fact, possess unique biological properties which render them promising candidate cells to be used in preclinical and clinical settings for tissue repair/regeneration.

This concise review will focus on the therapeutic applications of BM-MSCs for skeletal and cardiac muscle repair/regeneration, paying particular attention to the mechanisms through which these cells exert their beneficial effects. 


\section{Bone Marrow-Derived Mesenchymal Stromal Cells (BM-MSCs)}

\subsection{Biological Properties}

MSCs constitute a rare population of adult stem cells, found in situ within all adult mammalian supportive stromal tissue compartments; however, their main source remains the bone marrow where they were first identified over 40 years ago [40,41]. These cells are defined on the basis of their plastic adherence in standard culture condition, a spindle-shaped appearance, their phenotypic characteristics and a capability to be induced to differentiate into adipocytes, osteoblasts and chondrocytes. The phenotype definition requires the expression of CD73 (an ecto-5'-nucleotidae, involved in bone marrow stromal interactions, MSC migration and modulation of adaptive immunity), CD90 (Thy1 antigen, with unknown function) and CD105 (or endoglin, the transforming growth factor (TGF)- $\beta$ receptor III implicated in MSC chondrogenic differentiation) together with the lack of expression of $\mathrm{CD} 11 \mathrm{~b}$ and CD14 (monocyte and macrophage markers), CD34 (hematopoietic progenitor and endothelial cell marker), CD45 (leukocyte marker) CD19 or CD79a (B cell marker) and human leukocyte antigen (HLA)-DR surface molecules [42,43]. Despite these well-established criteria for defining MSCs, their isolation is hindered by the possible contamination of non-mesenchymal cells, resulting in a heterogeneous cell population with unpredictable MSC content [44]. Therefore, alternative preparation strategies have been recently postulated to improve the purity of the cell culture, such as the use of novel antibodies with specific reactivity against cell surface molecules highly expressed by MSCs (Stro-1, Stro-3, Stro-4, CD71, VCAM-1) [44,45]. MSCs possess many biological properties that make these cells ideal candidates for tissue engineering and regenerative medicine. These properties include: the ease of accessibility for isolation from the patients or bone marrow banks; the high expansion potential [46,47]; and, the presumptive plasticity, that is, being able to differentiate in vitro, not only into mesenchymal, but also non-mesenchymal lineages, including myoblasts [48], cardiomyocytes [49,50], hepatocyte-like cells [51], neuronal and neuroglial cells [52,53] and endothelial cells [54]. Moreover, when transplanted systemically, MSCs are able to migrate and home to the specific site of injury [55,56] and exert anti-inflammatory and immunosuppressive effects thus allowing a potential for their autologous and allogenic use [57-59]. Moreover, the absence of ethical issues concerning their tissue source and the lack of tumorigenicity represent additional advantages for their use in clinical applications [60,61].

\subsection{Contribution of BM-MSCs to Muscle Repair/Regeneration}

A large body of experimental evidence has shown that transplantation of BM-MSCs in animal models of muscle injury and disease has great therapeutic potential [6,62]. Indeed, the systemic or local administration of BM-MSCs into skeletal muscles subjected to traumatic injuries such as laceration [63], crush [64-66] or cardiotoxin injection [67,68], have been demonstrated to contribute to myofiber formation and to the functional recovery of the muscle tissue. A considerable augment in the capillary density and collateral perfusion, associated with a reduction of myofiber atrophy and disarray has also been observed in ischemic skeletal muscles transplanted with BM-MSCs [69-71]. Moreover, some studies reported that the injection of BM-MSCs into dystrophic muscles is capable to restore dystrophin expression [67,72-74], attenuate the oxidative stress [75], and improve the motor 
function [74]. Positive outcomes have been also obtained when BM-MSCs were utilized for treating post-myocardial infarction heart failure in both small (mouse and rat) and large animal (swine and dog) models. The administration of BM-MSCs (either by intravascular, intramyocardial or transendocardial injection), have in fact provided comprehensive functional benefits which include: attenuation of left ventricular negative remodelling with a reduction of the infarct size, increase of vascular density and myocardial perfusion [76-84], preservation of residual myocardium, and improvement of the contractile [76-78,81,85-88] and electrical properties [89,90]. However, despite these positive findings, there are controversies on the actual ability of BM-MSC to regenerate contracting myocardial tissue. Moreover, their retention and engraftment after transplantation into the diseased muscle still remain major limitations [76,77,91].

A number of clinical trials using autologous and allogenic BM-MSCs have been performed to improve the cardiac function in patients with acute myocardial infarction, or affected by chronic ischemic cardiomyopathy (Table 1). These studies have been proven to be generally safe and feasible without notable side effects; moreover, patients receiving BM-MSC therapy have experienced clinical benefits mainly in terms of scar reduction, a decrease in arrhythmias, an attenuation of ventricular contraction dysfunctions and an increase in left ventricular ejection fraction [92-99].

However, despite the encouraging outcomes, a deeper understanding of BM-MSC biology is required in order to validate their effective therapeutic benefits for muscle tissue repair/regeneration and elucidate the potential risks of their use in clinical applications.

\subsection{Trophic Actions}

There is a general consensus that the beneficial effects of BM-MSCs observed in animal models of human muscle disease, including acute and chronic myocardial infarction and dystrophy are mainly dependent on the trophic activity of the administered cells, rather than to their plasticity or stemness potential [100-104]. Many studies have shown, in fact, that MSCs do not differentiate into the cells of the injured organs and exert transient therapeutic effects in the absence of significant long-term engraftment (the injected cells are, in fact, rapidly lost after days from implantation) $[105,106]$. However, the implanted cells are metabolically and functionally active, capable of producing paracrine trophic factors with multiple effects in the host tissue microenvironment, including modulation of the endogenous repair mechanisms and prevention of injured cells from the stress response and apoptosis [106,107]. In this line, our group and others have shown that BM-MSCs produce, under normal culture conditions, a wide array of growth factors and cytokines $[108,109]$ and can be activated to express and release higher levels of therapeutic factors in response to stress or inflammation signals $[110,111]$. While the administration of various single growth factors have demonstrated beneficial results in skeletal [112-115] and cardiac regeneration [116-119], the unique value of MSC-therapy resides in the possibility to obtain local, constant and biologically effective levels of different functionally synergistic trophic factors in the contest of the regenerating tissue and to achieve more sustained therapeutic effects. The best studied paracrine factors produced by BM-MSCs are those involved in the regulation of the innate immunity; accumulating evidence during the last years have, in fact, demonstrated that BM-MSCs have distinctive immunomodulatory and anti-inflammatory properties [58]. 
Table 1. Clinical trials using BM-MSC therapy for cardiac repair/regeneration.

\begin{tabular}{|c|c|c|c|c|c|c|c|c|}
\hline Trial Name & $\begin{array}{l}\text { ClinicalTrials.gov } \\
\text { Identifier }\end{array}$ & Sponsor/ Collaborator & Location & Disease & Source & $\begin{array}{l}\text { Route of } \\
\text { Delivery }\end{array}$ & Patients & Status \\
\hline $\begin{array}{l}\text { Prospective randomized study of } \\
\text { mesenchymal stem cell therapy in patients } \\
\text { undergoing cardiac surgery } \\
\text { (PROMETHEUS) }\end{array}$ & NCT00587990 & $\begin{array}{l}\text { National Heart, Lung, and Blood } \\
\text { Institute (NHLBI) } \\
\text { Johns Hopkins University Specialized } \\
\text { Center for Cell Based Therapy }\end{array}$ & USA & $\begin{array}{l}\text { Chronic ischemic left } \\
\text { ventricular disfunction }\end{array}$ & Autologous & $\begin{array}{l}\text { Intramyocardia } \\
1 \text { injection }\end{array}$ & 45 & Completed \\
\hline $\begin{array}{l}\text { Stem cell injection to treat heart damage } \\
\text { during open heart surgery }\end{array}$ & NCT01557543 & $\begin{array}{l}\text { National Heart, Lung, and Blood } \\
\text { Institute (NHLBI) }\end{array}$ & USA & $\begin{array}{l}\text { Heart disease } \\
\text { Ischemic heart disease } \\
\text { Coronary artery disease }\end{array}$ & Autologous & $\begin{array}{l}\text { Intramyocardia } \\
1 \text { injection }\end{array}$ & 24 & Recruiting \\
\hline $\begin{array}{l}\text { Safety and efficacy of intracoronary adult } \\
\text { human mesenchymal stem cells after acute } \\
\text { myocardial infarction }\end{array}$ & NCT01392105 & $\begin{array}{l}\text { Yonsei University } \\
\text { FCB } \\
\text { Pharmicell Co Ltd. }\end{array}$ & $\begin{array}{l}\text { Republic } \\
\text { of Korea }\end{array}$ & $\begin{array}{l}\text { Acute myocardial } \\
\text { infarction } \\
\text { (AMI) }\end{array}$ & Autologous & $\begin{array}{l}\text { Intracoronary } \\
\text { injection }\end{array}$ & 80 & Completed \\
\hline $\begin{array}{l}\text { Stem cell therapy for vasculogenesis in } \\
\text { patients with severe myocardial ischemia }\end{array}$ & NCT00260338 & $\begin{array}{l}\text { Righospitalet, Copenhagen Denmark } \\
\text { Jens Kastrup }\end{array}$ & Denmark & $\begin{array}{l}\text { Myocardial ischemia } \\
\text { Coronary heart disease }\end{array}$ & Autologous & $\begin{array}{l}\text { Intramyocardia } \\
1 \text { injection }\end{array}$ & 31 & Completed \\
\hline $\begin{array}{l}\text { Autologous mesenchymal stromal cell } \\
\text { therapy in heart failure }\end{array}$ & NCT00644410 & $\begin{array}{l}\text { Righospitalet, Copenhagen Denmark } \\
\text { Jens Kastrup }\end{array}$ & Denmark & Heart failure & Autologous & $\begin{array}{l}\text { Intramyocardia } \\
1 \text { injection }\end{array}$ & 60 & Recruiting \\
\hline $\begin{array}{l}\text { Prochymal }{ }^{\circledR} \text { (human adult stem cells) } \\
\text { intravenous infusion following acute } \\
\text { myocardial infarction (AMI) }\end{array}$ & NCT00877903 & Osiris Therapeutics & $\begin{array}{l}\text { USA } \\
\text { Canada }\end{array}$ & $\begin{array}{l}\text { Acute myocardial } \\
\text { infarction } \\
\text { (AMI) }\end{array}$ & Allogenic & $\begin{array}{l}\text { Intravenous } \\
\text { injection }\end{array}$ & 220 & $\begin{array}{l}\text { Active, } \\
\text { not } \\
\text { recruiting }\end{array}$ \\
\hline $\begin{array}{l}\text { Safety Study of AMI MultiStem }{ }^{\circledR} \text { to treat } \\
\text { Heart attacks }\end{array}$ & NCT00677222 & $\begin{array}{l}\text { Athersys, Inc } \\
\text { PPD } \\
\text { Angiotech Pharmaceuticals }\end{array}$ & USA & $\begin{array}{l}\text { Acute myocardial } \\
\text { infarction } \\
\text { (AMI) }\end{array}$ & Allogenic & $\begin{array}{l}\text { Via catheter into } \\
\text { peri-vascular } \\
\text { space injection }\end{array}$ & 25 & Completed \\
\hline $\begin{array}{l}\text { A phase II dose-escalation study to assess } \\
\text { the feasibility and safety of transendocardial } \\
\text { delivery of three different doses of } \\
\text { allogeneic mesenchymal precursor cells } \\
\text { (MPCs) in subjects with heart failure }\end{array}$ & NCT00721045 & Angioblast Systems, U.S. & USA & Heart failure & Allogenic & $\begin{array}{l}\text { Trans- } \\
\text { endocardial } \\
\text { injection }\end{array}$ & 60 & $\begin{array}{l}\text { Unknown } \\
\text { (last verified } \\
\text { June 2010: } \\
\text { active, not } \\
\text { recruiting) }\end{array}$ \\
\hline
\end{tabular}


This notion is remarkable, but not surprising; wide evidence, in fact, suggests that communication of BM-MSCs and cells of the immune system starts at the level of the bone marrow niche, where it play a crucial role in maintaining and preserving the undifferentiated state of the hematopoietic stem cells [41]. Recent in vivo and in vitro observations have demonstrated that the crosstalk between BM-MSCs and the innate immunity results from a combination of direct cell-cell contact and soluble factor-mediated mechanisms, including the release of molecules and bioactive metabolites with immunomodulatory action, such as interleukin (IL)-10, transforming growth factor (TGF)- $\beta$, galectin-1, galectin-3, leukemia inhibitory factor (LIF), nitric oxide and prostaglandin E2 (PGE2) [58]. A clear example of these interactions is the documented ability of BM-MSCs to mediate the transition of classically activated M1 macrophages into anti-inflammatory M2 macrophages, which participate in tissue healing, promoting the resolution of inflammation and the clearance of apoptotic cells [120,121]. The crosstalk between BM-MSCs and macrophages is further highlighted by the findings showing that BM-MSCs can prevent the release of tumor necrosis factor (TNF)- $\alpha$ and other inflammatory chemokines from activated macrophages, through the secretion of IL-1 receptor antagonist (IL-1RA) [122], and stimulate monocytes to release IL-1 $\beta$, thus enhancing MSC-mediated secretion of TGF- $\beta$ and the subsequent T lymphocyte suppression [123]. Beyond the inhibition of macrophage function, BM-MSCs also sustain the survival and the suppressive phenotypes of $\mathrm{T}$ regulatory lymphocytes, interfere with differentiation of dendritic cells and B lymphocytes, and inhibit proliferation and functionality of natural killer (NK) cells [124]. All these findings, together with the observation that BM-MSCs are immunoprivileged cells, owing to the low expression levels of HLA major histocompatibility complex (MHC) class I and co-stimulatory molecules, have raised the clinical interest in these cells, exploiting the possibility of a universal donor of BM-MSCs for therapeutic applications.

In addition to these effects, transplanted BM-MSCs may facilitate other complementary aspects of tissue repair, which, however, are considered prerequisites for tissue reconstitution and functional improvement and include augmentation of cell survival (limited apoptosis), promotion of angiogenesis and vasculogenesis, and inhibition of scarring (fibrosis). They are mediated in large part by a number of MSC-secreted factors which are capable of: (i) activating pro-survival pathways in the transplanted as well as resident viable cells ((IL-6 and IL-10, stromal cell-derived factor 1(SDF-1)) [125-128]; (ii) stimulating blood vessel growth (VEGF, fibroblast growth factor (FGF), IL-1, matrix metalloproteinases (MMPs), platelet derived growth factor (PDGF), TGF- $\beta$, angiopoetin) [129,130]; (iii) promoting favourable extracellular matrix remodeling (IL-10) and altering the passive characteristics of the scar [131]; and, (iv) inhibiting fibroblast-myofibroblast transition and the following collagen synthesis and deposition (hepatocyte growth factor-HGF, adrenomedullin) [132-134].

Interestingly, it has been recently shown that BM-MSCs might affect cardiac or skeletal muscle repair via cytokine-induced enhancement of the host tissue (endogenous) stem cell function [135-137]. In this context, we have demonstrated in co-culture systems that BM-MSCs enhance neonatal cardiac as well as $\mathrm{C} 2 \mathrm{C} 12$ skeletal myoblast proliferation (Figure 1) through a combination of juxtacrine and paracrine mechanisms that involve the activation of Notch-1 signaling [108,109]. We have also shown that these effects were mainly mediated by the release of VEGF by BM-MSCs [109]. Consistent with these findings, in vivo experiments have shown that injection of BM-MSCs promote the activation of muscle satellite cells and the formation of new myofibers in the injected skeletal muscles [75]. 
Moreover, the engrafted BM-MSCs can directly participate in the recruitment and differentiation of the endogenous cardiac progenitor cells in the diseased myocardium, via the paracrine release of SDF-1 $\alpha$, a potent chemoattractant for stem cells $[127,138]$.

Figure 1. Bone marrow-derived mesenchymal stromal cells (BM-MSCs) stimulate proliferation of muscle progenitor cells. Representative superimposed differential interference contrast (DIC) and confocal fluorescence images showing the pyrimidine analogue EdU (5-ethynyl-2'-deoxyuridine) staining (green) in the nuclei of proliferating murine $\mathrm{C} 2 \mathrm{C} 12$ skeletal myoblasts or murine neonatal cardiomyocytes in single and co-culture for $24 \mathrm{~h}$ with mouse Dil-labeled BM-MSCs (red). Note the higher number of proliferating cells in the co-culture systems.

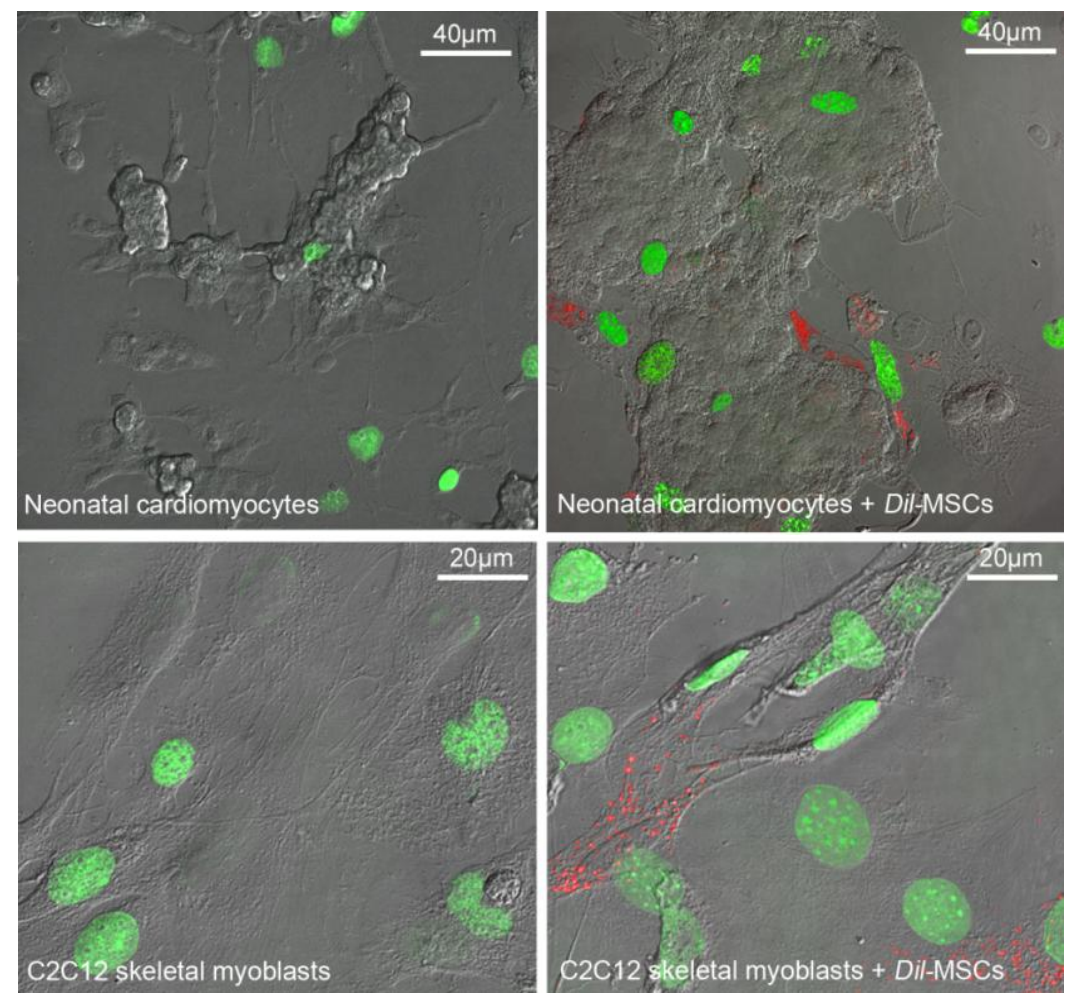

\subsection{Strategies to Advance the Therapeutic Properties of BM-MSCs}

Much emphasis is currently given to the identification of new strategies to optimize the cell fate after in vivo BM-MSC administration. These techniques target a wide array of biological functions, including the cell homing, survival, proliferation and paracrine secretion. Studies have shown that preconditioning by exposure to reduced levels of oxygen, incubation with nitric oxide, hydrogen peroxide or diazoxide, and treatment with pharmacological drugs, including phosphodiesterase inhibitors, angiotensin II receptor blocker and neuropeptide Y, may greatly enhance the therapeutic promise of BM-MSCs [44]. Moreover, it has been recently shown by our group that the treatment with platelet-derived rich plasma (PRP) [139], as well as irradiation with low level lasers [140], represent promising preconditioning approaches for stimulating BM-MSC proliferation, encompassing senescence during cell expansion and influencing stemness gene expression. Of interest, the genetic manipulation of MSC to overexpress cytokines and growth factors, such as HGF, VEGF and SDF-1, 
have also been proposed to improve neo-angiogenesis and the endogenous mechanisms of tissue repair/regeneration [44,141,142]. Finally, bioengineered three-dimensional matrices have been shown to represent appropriate devices to preserve the survival of the engrafted MSCs and assist their migration within the damaged tissues [139,143,144].

\section{Conclusions and Future Perspectives}

BM-MSCs are considered among the best candidates for cell-based therapy for skeletal and cardiac muscle repair/regeneration. Their beneficial effects are mainly related to the release of a wide range of trophic factors with multiple effects in the host tissue (Scheme 1). Of particular interest are the findings showing that BM-MSCs stimulate proliferation and differentiation of the resident muscle progenitors, providing novel concepts for considering these cells as instructing and supporting elements capable of modulating the endogenous tissue repair mechanisms. In vitro priming of BM-MSCs by a wide variety of techniques may be used to complement the biological and biochemical properties of these cells and allow the expansion of their therapeutic potential. However, at present, the clinical application of BM-MSCs is considered with caution and long-term studies are still required in order to elucidate the side effects and validate the safety of these cells for tissue regeneration.

Scheme 1. Therapeutic paracrine effects of bone marrow derived mesenchymal stromal cells (BM-MSCs) for skeletal and cardiac muscle repair/regeneration. Abbreviations: ECM: Extracellular matrix; FGF: Fibroblast growth factor; HGF: Hepatocyte growth factor; IL-1: Interleukin 1; IL 6: Interleukin-6; IL-10: Interleukin 10; MMPs: Matrix metalloproteinases; PDGF: Platelet derived growth factor; TGF- $\beta$ : transforming growth factor- $\beta$; VEGF: Vascular endothelial growth factor; SDF-1: stromal derived factor-1; IL-1RA: interleukin 1 receptor antagonist; PGE2: prostaglandin E2; LIF: leukemia inhibitory factor; NO: Nitric oxide.

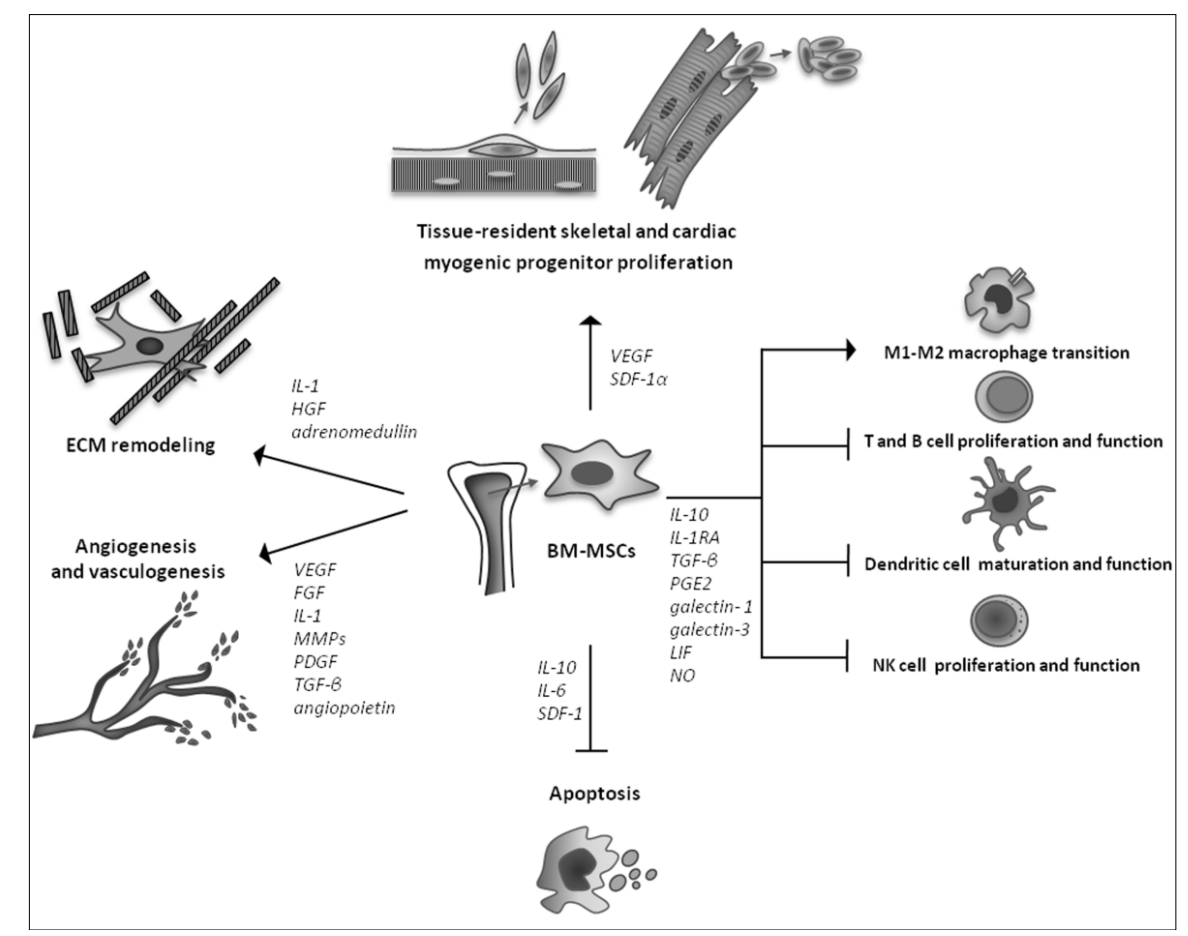




\section{Conflict of Interest}

The authors declare no conflict of interest.

\section{References}

1. Buckingham, M.; Montarras, D. Skeletal muscle stem cells. Curr. Opin. Genet. Dev. 2008, 18, 330-336.

2. Chargè, S.B.; Rudnicki, M.A. Cellular and molecular regulation of muscle regeneration. Physiol. Rev. 2004, 84, 209-238.

3. Dhawan, J.; Rando, T.A. Stem cells in postnatal myogenesis: molecular mechanisms of satellite cell quiescence, activation and replenishment. Trends Cell. Biol. 2005, 15, 666-673.

4. Tidball, J.G.; Villalta, S.A. Regulatory interactions between muscle and the immune system during muscle regeneration. Am. J. Physiol. Regul. Integr. Comp. Physiol. 2010, 298, R1173-R1187.

5. Ten Broek, R.W.; Grefte, S.; von den Hoff, J.W. Regulatory factors and cell populations involved in skeletal muscle regeneration. J. Cell. Physiol. 2010, 224, 7-16.

6. Turner, N.J.; Badyak, S.F. Regeneration of skeletal muscle. Cell. Tissue Res. 2012, 347, 759-774.

7. Filippin, L.I.; Moreira, A.J.; Marroni, N.P.; Xavier, R.M. Nitric oxide and repair of skeletal muscle injury. Nitric. Oxide. 2009, 21, 157-163.

8. Wang, W.; Pan, H.; Murray, K.; Jefferson, B.S.; Li, Y. Matrix metalloproteinase-1 promotes muscle cell migration and differentiation. Am. J. Pathol. 2009, 174, 541-549.

9. Carosio, S.; Berardinelli, M.G.; Aucello, M.; Musarò, A. Impact of ageing on muscle cell regeneration. Ageing Res. Rev. 2011, 10, 35-42.

10. Laugwitz, K.L.; Moretti, A.; Lam, J.; Gruber, P.; Chen, Y.; Woodard, S.; Lin, L.Z.; Cai, C.L.; Lu, M.M.; Reth, M.; et al. Postnatal is $11^{+}$cardioblasts enter fully differentiated cardiomyocyte lineages. Nature 2005, 433, 647-653.

11. Anversa, P.; Kajstura, J.; Leri, A.; Bolli, R. Life and Death of Cardiac Stem Cells A Paradigm Shift in Cardiac Biology. Circulation 2006, 113, 1451-1463.

12. Di Nardo, P.; Forte, G.; Ahluwalia, A.; Minieri, M. Cardiac progenitor cells: Potency and control. J. Cell. Physiol. 2010, 224, 590-600.

13. Bani, D.; Formigli, L.; Gherghiceanu, M.; Faussone-Pellegrini, M.S. Telocytes as supporting cells for myocardial tissue organization in developing and adult heart. J. Cell. Mol. Med. 2010, 14, 2531-2538.

14. Balmer, G.M.; Riley, P.R. Harnessing the Potential of Adult Cardiac Stem Cells: Lessons from Haematopoiesis, the Embryo and the Niche. J. Cardiovasc. Transl. Res. 2012, 5, 631-640.

15. Torella, D.; Ellison, G.M.; Méndez-Ferrer, S.; Ibanez, B.; Nadal-Ginard, B. Resident human cardiac stem cells: Role in cardiac cellular homeostasis and potential for myocardial regeneration. Nat. Clin. Pract. Cardiovasc Med. 2006, 3, S8-S13.

16. van Amerongen, M.J.; Engel, F.B. Features of cardiomyocyte proliferation and its potential for cardiac regeneration. J. Cell. Mol. Med. 2008, 12, 2233-2244.

17. Noort, W.A.; Sluijter, J.P.; Goumans, M.J.; Chamuleau, S.A.; Doevendans, P.A. Stem cells from 
in- or outside of the heart: Isolation, characterization, and potential for myocardial tissue regeneration. Pediatr. Cardiol. 2009, 30, 699-709.

18. Hsieh, P.C.; Segers, V.F.; Davis, M.E.; MacGillivray, C.; Gannon, J.; Molkentin, J.D.; Robbins, J.; Lee, R.T. Evidence from a genetic fate-mapping study that stem cells refresh adult mammalian cardiomyocytes after injury. Nat. Med. 2007, 13, 970-974.

19. Lyngbaek, S.; Schneider, M.; Hansen, J.L.; Sheikh, S.P. Cardiac regeneration by resident stem and progenitor cells in the adult heart. Basic Res. Cardiol. 2007, 102, 101-114.

20. Leri, A.; Kajstura, J.; Anversa, P.; Frishman, W.H. Myocardial regeneration and stem cell repair. Curr. Probl. Cardiol. 2008, 33, 91-153.

21. Altarche-Xifró, W.; Curato, C.; Kaschina, E.; Grzesiak, A.; Slavic, S.; Dong, J.; Kappert, K.; Steckelings, M.; Imboden, H.; Unger, T.; et al. Cardiac c-kit ${ }^{+} \mathrm{AT}^{+}$cell population is increased in response to ischemic injury and supports cardiomyocyte performance. Stem Cells 2009, 27, $2488-2497$.

22. Cossu, G.; Sampaolesi, M. New therapies for muscular dystrophy: Cautious optimism. Trends Mol. Med. 2004, 10, 516-520.

23. Price, F.D.; Kuroda, K.; Rudnicki M.A. Stem cell based therapies to treat muscular dystrophy. Biochim. Biophys. Acta 2007, 1772, 272-283.

24. Formigli, L.; Zecchi-Orlandini, S.; Meacci, E.; Bani, D. Skeletal myoblasts for heart regeneration and repair: state of the art and perspectives on the mechanisms for functional cardiac benefits. Curr. Pharm. Des. 2010, 16, 915-928.

25. Negroni, E.; Vallese, D.; Vilquin, J.T.; Butler-Browne, G.; Mouly, V.; Trollet, C. Current advances in cell therapy strategies for muscular dystrophies. Expert Opin. Biol. Ther. 2011, 11, 157-176.

26. Abdelwahid, E.; Siminiak, T.; Guarita-Souza, L.C.; Teixeira de Carvalho, K.A.; Gallo, P.; Shim, W.; Condorelli, G. Stem cell therapy in heart diseases: A review of selected new perspectives, practical considerations and clinical applications. Curr. Cardiol. Rev. 2011, 7, 201-212.

27. Choi, S.H.; Jung, S.Y.; Kwon, S.M.; Baek, S.H. Perspectives on stem cell therapy for cardiac regeneration. Circ. J. 2012, 76, 1307-1312.

28. Tedesco, F.S.; Dellavalle, A.; Diaz-Manera, J.; Messina, G.; Cossu, G. Repairing skeletal muscle: regenerative potential of skeletal muscle stem cells. J. Clin. Invest. 2010, 120, 11-19.

29. Montarras, D.; Morgan, J.; Collins, C.; Relaix, F.; Zaffran, S.; Cumano, A.; Partridge, T.; Buckingham, M. Direct isolation of satellite cells for skeletal muscle regeneration. Science 2005, 309, 2064-2067.

30. Biressi, S.; Rando, T.A. Heterogeneity in the muscle satellite cell population.Semin Cell. Dev. Biol. 2010, 21, 845-854.

31. Huang, Y.C.; Dennis, R.G.; Baar, K. Cultured slow vs. fast skeletal muscle cells differ in physiology and responsiveness to stimulation. Am. J. Physiol. Cell. Physiol. 2006, 291, C11-C17.

32. Harel, I.; Nathan, E.; Tirosh-Finkel, L.; Zigdon, H.; Guimarães-Camboa, N.; Evans, S.M.; Tzahor, E. Distinct origins and genetic programs of head muscle satellite cells. Dev. Cell. 2009, $16,822-832$. 
33. Sammels, L.M.; Bosio, E.; Fragall, C.T.; Grounds, M.D.; van Rooijen, N.; Beilharz, M.W. Innate inflammatory cells are not responsible for early death of donor myoblasts after myoblast transfer therapy. Transplantation 2004, 77, 1790-1797.

34. Chimenti, I.; Gaetani, R.; Barile, L.; Frati, G.; Messina, E.; Giacomello, A. c-kit cardiac progenitor cells: What is their potential? Proc. Natl. Acad. Sci. USA 2009, 106, E78.

35. Itzhaki-Alfia, A.; Leor, J.; Raanani, E.; Sternik, L.; Spiegelstein, D.; Netser, S.; Holbova, R.; Pevsner-Fischer, M.; Lavee, J.; Barbash, I.M. Patient characteristics and cell source determine the number of isolated human cardiac progenitor cells. Circulation 2009, 120, 2559-2566.

36. Miyamoto, S.; Kawaguchi, N.; Ellison, G.M.; Matsuoka, R.; Shin'oka, T.; Kurosawa, H. Characterization of long-term cultured $\mathrm{c}-\mathrm{kit}^{+}$cardiac stem cells derived from adult rat hearts. Stem Cells Dev. 2010, 19, 105-116.

37. Ellison, G.M.; Galuppo, V.; Vicinanza, C.; Aquila, I.; Waring, C.D.; Leone, A.; Indolfi, C.; Torella, D. Cardiac stem and progenitor cell identification: different markers for the same cell? Front. Biosci. (Schol. Ed.). 2010, 1, 641-652.

38. Forte, G.; Pietronave, S.; Nardone, G.; Zamperone, A.; Magnani, E.; Pagliari, S.; Pagliari, F.; Giacinti, C.; Nicoletti, C.; Musaró, A.; et al. Human cardiac progenitor cell grafts as unrestricted source of supernumerary cardiac cells in healthy murine hearts. Stem Cells 2011, 29, 2051-2061.

39. He, J.Q.; Vu, D.M.; Hunt, G.; Chugh, A.; Bhatnagar, A.; Bolli, R. Human cardiac stem cells isolated from atrial appendages stably express c-kit. PLoS One 2011, 6, e27719.

40. Friedenstein, A.J.; Petrakova, K.V.; Kurolesova, A.I.; Frolova, G.P. Heterotopic of bone marrow. Analysis of precursor cells for osteogenic and hematopoietic tissues. Transplantation 1968, 6, 230-247.

41. Méndez-Ferrer, S.; Michurina, T.V.; Ferraro, F.; Mazloom, A.R.; Macarthur, B.D.; Lira, S.A.; Scadden, D.T.; Ma'ayan, A.; Enikolopov, G.N.; Frenette, P.S. Mesenchymal and haematopoietic stem cells form a unique bone marrow niche. Nature 2010, 466, 829-834.

42. Dominici, M.; Le Blanc, K.; Mueller, I.; Slaper-Cortenbach, I.; Marini, F.; Krause, D.; Deans, R.; Keating, A.; Prockop, D.J.; Horwitz, E. Minimal criteria for defining multipotent mesenchymal stromal cells. The International Society for Cellular Therapy position statement. Cytotherapy 2006, 8, 315-317.

43. Boxall, S.A.; Jones, E. Markers for characterization of bone marrow multipotential stromal cells. Stem Cells Int. 2012, 2012, 975871.

44. Richardson, J.D.; Nelson, A.J.; Zannettino, A.C.; Gronthos, S.; Worthley, S.G.; Psaltis, P.J. Optimization of the Cardiovascular Therapeutic Properties of Mesenchymal Stromal/Stem Cells-Taking the Next Step. Stem Cell. Rev. 2012, in press.

45. Salem, H.K.; Thiemermann, C. Mesenchymal stromal cells: Current understanding and clinical status. Stem Cells 2010, 28, 585-596.

46. Zhironkina, O.A.; Shipounova, I.N.; Bigildeev, A.E.; Sats, N.V.; Petinati, N.A.; Drize, N.I. Proliferative potential of multipotent mesenchymal stromal cells from human bone marrow. Bull. Exp. Biol. Med. 2012, 152, 543-547.

47. Haack-Sørensen, M.; Hansen, S.K.; Hansen, L.; Gaster, M.; Hyttel, P.; Ekblond, A.; Kastrup, J. Mesenchymal stromal cell phenotype is not influenced by confluence during culture expansion. Stem Cell. Rev. 2012, in press. 
48. Wakitani, S.; Saito, T.; Caplan, A.I. Myogenic cells derived from rat bone marrow mesenchymal stem cells exposed to 5-azacytidine. Muscle Nerve 1995, 18, 1417-1426.

49. Makino, S.; Fukuda, K.; Miyoshi, S.; Konishi, F.; Kodama, H.; Pan, J.; Sano, M.; Takahashi, T.; Hori, S.; Abe, H.; et al. Cardiomyocytes can be generated from marrow stromal cells in vitro. J. Clin. Invest. 1999, 103, 697-705.

50. He, X.Q.; Chen, M.S.; Li, S.H.; Liu, S.M.; Zhong, Y.; McDonald Kinkaid, H.Y.; Lu, W.Y.; Weisel, R.D.; Li, R.K. Co-culture with cardiomyocytes enhanced the myogenic conversion of mesenchymal stromal cells in a dose-dependent manner. Mol. Cell. Biochem. 2010, 339, 89-98.

51. Schwartz, R.E.; Reyes, M.; Koodie, L.; Jiang, Y.; Blackstad, M.; Lund, T.; Lenvik, T.; Johnson, S.; Hu, W.S.; Verfaillie, C.M. Multipotent adult progenitor cells from bone marrow differentiate into functional hepatocyte-like cells. J. Clin. Invest. 2002, 109, 1291-1302.

52. Woodbury, D.; Schwarz, E.J.; Prockop, D.J.; Black, I.B. Adult rat and human bone marrow stromal cells differentiate into neurons. J. Neurosci. Res. 2000, 61, 364-370.

53. Sanchez-Ramos, J.; Song, S.; Cardozo-Pelaez, F.; Hazzi, C.; Stedeford, T.; Willing, A.; Freeman, T.B.; Saporta, S.; Janssen, W.; Patel, N.; et al. Adult bone marrow stromal cells differentiate into neural cells in vitro. Exp. Neurol. 2000, 164, 247-256.

54. Oswald, J.; Boxberger, S.; Jørgensen, B.; Feldmann, S.; Ehninger, G.; Bornhäuser, M.; Werner, C. Mesenchymal stem cells can be differentiated into endothelial cells in vitro. Stem Cells 2004, 22, 377-384.

55. Chapel, A.; Bertho, J.M.; Bensidhoum, M.; Fouillard, L.; Young, R.G.; Frick, J.; Demarquay, C.; Cuvelier, F.; Mathieu, E.; Trompier, F.; et al. Mesenchymal stem cells home to injured tissues when co-infused with hematopoietic cells to treat a radiation-induced multi-organ failure syndrome. J. Gene Med. 2003, 5, 1028-1038.

56. Chamberlain, G.; Fox, J.; Ashton, B.; Middleton, J. Concise review: Mesenchymal stem cells: Their phenotype, differentiation capacity, immunological features, and potential for homing. Stem Cells 2007, 25, 2739-2749.

57. Yi, T.; Song, S.U. Immunomodulatory properties of mesenchymal stem cells and their therapeutic applications. Arch. Pharm. Res. 2012, 35, 213-221.

58. Le Blanc, K.; Mougiakakos, D. Multipotent mesenchymal stromal cells and the innate immune system. Nat. Rev. Immunol. 2012, 12, 383-396.

59. Baiguera, S.; Jungebluth, P.; Mazzanti, B.; Macchiarini, P. Mesenchymal stromal cells for tissue-engineered tissue and organ replacements. Transpl. Int. 2012, 25, 369-382.

60. von Bahr, L.; Batsis, I.; Moll, G.; Hägg, M.; Szakos, A.; Sundberg, B.; Uzunel, M.; Ringden, O.; Le Blanc, K. Analysis of tissues following mesenchymal stromal cell therapy in humans indicates limited long-term engraftment and no ectopic tissue formation. Stem Cells 2012, 30, $1575-1578$.

61. Wang, Y.; Han, Z.B.; Song, Y.P.; Han, Z.C. Safety of mesenchymal stem cells for clinical application. Stem Cells Int. 2012, 2012, 652034.

62. Cashman, T.J.; Gouon-Evans, V.; Costa, K.D. Mesenchymal Stem Cells for Cardiac Therapy: Practical Challenges and Potential Mechanisms. Stem Cell. Rev. 2012, in press. 
63. Natsu, K.; Ochi, M.; Mochizuki, Y.; Hachisuka, H.; Yanada, S.; Yasunaga, Y. Allogeneic bone marrow-derived mesenchymal stromal cells promote the regeneration of injured skeletal muscle without differentiation into myofibers. Tissue Eng. 2004, 10, 1093-1112.

64. Matziolis, G.;Winkler, T.; Schaser, K.; Wiemann, M.; Krocker, D.; Tuischer, J.; Perka, C.; Duda, G.N. Autologous bone marrow-derived cells enhance muscle strength following skeletal muscle crush injury in rats. Tissue Eng. 2006, 12, 361-367.

65. Winkler, T.; von Roth, P.; Radojewski, P.; Urbanski, A.; Hahn, S.; Preininger, B.; Duda, G.N.; Perka, C. Immediate and delayed transplantation of mesenchymal stem cells improve muscle force after skeletal muscle injury in rats. J. Tissue Eng. Regen. Med. 2012, doi:10.1002/term. 1542.

66. von Roth, P.; Duda, G.N.; Radojewski, P.; Preininger, B.; Perka, C.; Winkler, T. Mesenchymal stem cell therapy following muscle trauma leads to improve muscular regeneration in both male and female rats. Gend. Med. 2012, 9, 129-136.

67. Dezawa, M.; Ishikawa, H.; Itokazu, Y.; Yoshihara, T.; Hoshino, M.; Takeda, S.; Ide, C.; Nabeshima, Y. Bone marrow stromal cells generate muscle cells and repair muscle degeneration. Science 2005, 309, 314-317.

68. de la Garza-Rodea, A.S.; van der Velde, I.; Boersma, H.; Gonçalves, M.A.; van Bekkum, D.W.; de Vries, A.A.; Knaän-Shanzer, S. Long-term contribution of human bone marrow mesenchymal stromal cells to skeletal muscle regeneration in mice. Cell Transplant. 2011, 20, 217-231.

69. Kinnaird, T.; Stabile, E.; Burnett, M.S.; Shou, M.; Lee, C.W.; Barr, S.; Fuchs, S.; Epstein, S.E. Local delivery of marrow-derived stromal cells augments collateral perfusion through paracrine mechanisms. Circulation 2004, 109, 1543-1549.

70. Hoffmann, J.; Glassford, A.J.; Doyle, T.C.; Robbins, R.C.; Schrepfer, S.; Pelletier, M.P. Angiogenic effects despite limited cell survival of bone marrow-derived mesenchymal stem cells under ischemia. Thorac. Cardiovasc. Surg. 2010, 58, 136-142.

71. Li, Y.; Zhang, D.; Zhang, Y.; He, G.; Zhang, F. Augmentation of neovascularization in murine hindlimb ischemia by combined therapy with simvastatin and bone marrow-derived mesenchymal stem cells transplantation. J. Biomed. Sci. 2010, 17, 75.

72. Feng, S.W.; Lu, X.L.; Liu, Z.S.; Zhang, Y.N.; Liu, T.Y.; Li, J.L.; Yu, M.J.; Zeng, Y.; Zhang, C. Dynamic distribution of bone marrow-derived mesenchymal stromal cells and change of pathology after infusing into mdx mice. Cytotherapy 2008, 10, 254-264.

73. Nitahara-Kasahara, Y.; Hayashita-Kinoh, H.; Ohshima-Hosoyama, S.; Okada, H.; Wada-Maeda, M.; Nakamura, A.; Okada, T.; Takeda, S. Long-term engraftment of multipotent mesenchymal stromal cells that differentiate to form myogenic cells in dogs with Duchenne muscular dystrophy. Mol. Ther. 2012, 20, 168-177.

74. Li, Z.; Liu, H.Y.; Lei, Q.F.; Zhang, C.; Li, S.N. Improved motor function in dko mice by intravenous transplantation of bone marrow-derived mesenchymal stromal cells. Cytotherapy 2011, 13, 69-77.

75. Shabbir, A.; Zisa, D.; Leiker, M.; Johnston, C.; Lin, H.; Lee, T. Muscular dystrophy therapy by nonautologous mesenchymal stem cells: muscle regeneration without immunosuppression and inflammation. Transplantation 2009, 87, 1275-1282. 
76. Amado, L.C.; Saliaris, A.P.; Schuleri, K.H.; St John, M.; Xie, J.S.; Cattaneo, S.; Durand, D.J.; Fitton, T.; Kuang, J.Q.; Stewart, G.; et al. Cardiac repair with intramyocardial injection of allogeneic mesenchymal stem cells after myocardial infarction. Proc. Natl. Acad. Sci. USA 2005, 102, 11474-11479.

77. Dai, W.; Hale, S.L.; Martin, B.J.; Kuang, J.Q.; Dow, J.S.; Wold, L.E.; Kloner, R.A. Allogeneic mesenchymal stem cell transplantation in postinfarcted rat myocardium: short- and long-term effects. Circulation 2005, 112, 214-223.

78. Perin, E.C.; Silva, G.V.; Assad, J.A.; Vela, D.; Buja, L.M.; Sousa, A.L.; Litovsky, S.; Lin, J.; Vaughn, W.K.; Coulter, S.; et al. Comparison of intracoronary and transendocardial delivery of allogeneic mesenchymal cells in a canine model of acute myocardial infarction. J. Mol. Cell. Cardiol. 2008, 44, 486-495.

79. Wang, C.C.; Chen, C.H.; Lin, W.W.; Hwang, S.M.; Hsieh, P.C.; Lai, P.H.; Yeh, Y.C.; Chang, Y.; Sung, H.W. Direct intramyocardial injection of mesenchymal stem cell sheet fragments improves cardiac functions after infarction. Cardiovasc. Res. 2008, 77, 515-524.

80. Vela, D.C.; Silva, G.V.; Assad, J.A.; Sousa, A.L.; Coulter, S.; Fernandes, M.R.; Perin, E.C.; Willerson, J.T.; Buja, L.M. Histopathological study of healing after allogenic mesenchymal stem cell delivery in myocardial infarction in dogs. J. Histochem. Cytochem. 2009, 57, 167-176.

81. Quevedo, H.C.; Hatzistergos, K.E.; Oskouei, B.N.; Feigenbaum, G.S.; Rodriguez, J.E.; Valdes, D.; Pattany, P.M.; Zambrano, J.P.; Hu, Q.; McNiece, I.; et al. Allogeneic mesenchymal stem cells restore cardiac function in chronic ischemic cardiomyopathy via trilineage differentiating capacity. Proc. Natl. Acad. Sci. USA 2009, 106, 14022-14027.

82. Schuleri, K.H.; Feigenbaum, G.S.; Centola, M.; Weiss, E.S.; Zimmet, J.M.; Turney, J.; Kellner, J.; Zviman, M.M.; Hatzistergos, K.E.; Detrick, B.; et al. Autologous mesenchymal stem cells produce reverse remodelling in chronic ischaemic cardiomyopathy. Eur. Heart J. 2009, 30, 2722-2732.

83. Psaltis, P.J.; Carbone, A.; Nelson, A.J.; Lau, D.H.; Jantzen, T.; Manavis, J.; Williams, K.; Itescu, S.; Sanders, P.; Gronthos, S.; et al. Reparative effects of allogeneic mesenchymal precursor cells delivered transendocardially in experimental nonischemic cardiomyopathy. JACC Cardiovasc. Interv. 2010, 3, 974-983.

84. Sato, T.; Iso, Y.; Uyama, T.; Kawachi, K.; Wakabayashi, K.; Omori, Y.; Soda, T.; Shoji, M.; Koba, S.; Yokoyama, S.; et al. Coronary vein infusion of multipotent stromal cells from bone marrow preserves cardiac function in swine ischemic cardiomyopathy via enhanced neovascularization. Lab. Invest. 2011, 91, 553-564.

85. Shake, J.G.; Gruber, P.J.; Baumgartner, W.A.; Senechal, G.; Meyers, J.; Redmond, J.M.; Pittenger, M.F.; Martin, B.J. Mesenchymal stem cell implantation in a swine myocardial infarct model: engraftment and functional effects. Ann. Thorac. Surg. 2002, 73, 1919-1925.

86. Makkar, R.R.; Price, M.J.; Lill, M.; Frantzen, M.; Takizawa, K.; Kleisli, T.; Zheng, J.; Kar, S.; McClelan, R.; Miyamota, T.; et al. Intramyocardial injection of allogenic bone marrow-derived mesenchymal stem cells without immunosuppression preserves cardiac function in a porcine model of myocardial infarction. J. Cardiovasc. Pharmacol. Ther. 2005, 10, 225-233.

87. Price, M.J.; Chou, C.C.; Frantzen, M.; Miyamoto, T.; Kar, S.; Lee, S.; Shah, P.K.; Martin, B.J.; Lill, M.; Forrester, J.S.; et al. Intravenous mesenchymal stem cell therapy early after reperfused 
acute myocardial infarction improves left ventricular function and alters electrophysiologic properties. Int. J. Cardiol. 2006, 111, 231-239.

88. Xu, H.; Yang, Y.J.; Qian, H.Y.; Tang, Y.D.; Wang, H.; Zhang, Q. Rosuvastatin treatment activates JAK-STAT Pathway and increases efficacy of allogeneic mesenchymal stem cell transplantation. Circ. J. 2011, 75, 1476-1485.

89. Mills, W.R.; Mal, N.; Kiedrowski, M.J.; Unger, R.; Forudi, F.; Popovic, Z.B.; Penn, M.S.; Laurita, K.R. Stem cell therapy enhances electrical viability in myocardial infarction. J. Mol. Cell. Cardiol. 2007, 42, 304-314.

90. Costa, A.R.; Panda, N.C.; Yong, S.; Mayorga, M.E.; Pawlowski, G.P.; Fan, K.; Penn, M.S.; Laurita, K.R. Optical mapping of cryoinjured rat myocardium grafted with mesenchymal stem cells. Am. J. Physiol. Heart Circ. Physiol. 2012, 302, H270-277.

91. Noiseux, N.; Gnecchi, M.; Lopez-Ilasaca, M.; Zhang, L.; Solomon, S.D.; Deb, A.; Dzau, V.J.; Pratt, R.E. Mesenchymal stem cells overexpressing Akt dramatically repair infarcted myocardium and improve cardiac function despite infrequent cellular fusion or differentiation. Mol. Ther. 2006, 14, 840-850.

92. Chong, J.J. Cell Therapy for Left Ventricular Dysfunction: An Overview for Cardiac Clinicians. Heart Lung Circ. 2012, 21, 532-542.

93. Chen, S.L.; Fang, W.W.; Ye, F.; Liu, Y.H.; Qian, J.; Shan, S.J.; Zhang, J.J.; Chunhua, R.Z.; Liao, L.M.; Lin, S.; et al. Effect on left ventricular function of intracoronary transplantation of autologous bone marrow mesenchymal stem cell in patients with acute myocardial infarction. Am. J. Cardiol. 2004, 94, 92-95.

94. Katritsis, D.G.; Sotiropoulou, P.A.; Karvouni, E.; Karabinos, I.; Korovesis, S.; Perez, S.A.; Voridis, E.M.; Papamichail, M. Transcoronary transplantation of autologous mesenchymal stem cells and endothelial progenitors into infarcted human myocardium. Catheter. Cardiovasc. Interv. 2005, 65, 321-329.

95. Chen, S.; Liu, Z.; Tian, N.; Zhang, J.; Yei, F.; Duan, B.; Zhu, Z.; Lin, S.; Kwan, T.W. Intracoronary transplantation of autologous bone marrow mesenchymal stem cells for ischemic cardiomyopathy due to isolated chronic occluded left anterior descending artery. J. Invasive Cardiol. 2006, 18, 552-556.

96. Hare, J.M.; Traverse, J.H.; Henry, T.D.; Dib, N.; Strumpf, R.K.; Schulman, S.P.; Gerstenblith, G.; De Maria, A.N.; Denktas, A.E.; Gammon, R.S.; et al. A randomized, double-blind, placebo-controlled, dose-escalation study of intravenous adult human mesenchymal stem cells (prochymal) after acute myocardial infarction. J. Am. Coll. Cardiol. 2009, 54, 2277-2286.

97. Chin, S.P.; Poey, A.C.; Wong, C.Y.; Chang, S.K.; Teh, W.; Mohr, T.J.; Cheong, S.K. Cryopreserved mesenchymal stromal cell treatment is safe and feasible for severe dilated ischemic cardiomyopathy. Cytotherapy 2010, 12, 31-37.

98. Chin, S.P.; Poey, A.C.; Wong, C.Y.; Chang, S.K.; Tan, C.S.; Ng, M.T.; Chew, K.H.; Lam, K.H.; Cheong, S.K. Intramyocardial and intracoronary autologous bone marrow-derived mesenchymal stromal cell treatment in chronic severe dilated cardiomyopathy. Cytotherapy 2011, 13, 814-821. 
99. Penn, M.S.; Ellis, S.; Gandhi, S.; Greenbaum, A.; Hodes, Z.; Mendelsohn, F.O.; Strasser, D.; Ting, A.E.; Sherman, W. Adventitial delivery of an allogeneic bone marrow-derived adherent stem cell in acute myocardial infarction: phase I clinical study. Circ. Res. 2012, 110, 304-311.

100. Caplan, A.I.; Dennis, J.E. Mesenchymal stem cells as trophic mediators. J. Cell. Biochem. 2006, 98, 1076-1084.

101. Shabbir, A.; Zisa, D.; Suzuki, G.; Lee, T. Heart failure therapy mediated by the trophic activities of bone marrow mesenchymal stem cells: A non invasive therapeutic regimen. Am. J. Physiol. Heart Circ. Physiol. 2009, 296, H1888-H1897.

102. Lee, R.H.; Pulin, A.A.; Seo, M.J.; Kota, D.J.; Ylostalo, J.; Larson, B.L.; Semprun-Prieto, L.; Delafontaine, P.; Prockop, D.J. Intravenous hMSCs improve myocardial infarction in mice because cells embolized in lung are activated to secrete the anti-inflammatory protein TSG-6. Cell Stem Cell 2009, 5, 54-63.

103. Burdon, T.J.; Paul, A.; Noiseux, N.; Prakash, S.; Shum-Tim, D. Bone marrow stem cell derived paracrine factors for regenerative medicine: current perspectives and therapeutic potential. Bone Marrow Res. 2011, 207326.

104. Lee, R.H.; Oh, J.Y.; Choi, H.; Bazhanov, N. Therapeutic factors secreted by mesenchymal stromal cells and tissue repair. J. Cell. Biochem. 2011, 112, 3073-3078.

105. Iso, Y.; Spees, J.L.; Serrano, C.; Bakondi, B.; Pochampally, R.; Song, Y.H.; Sobel, B.E.; Delafontaine, P.; Prockop, D.J. Multipotent human stromal cells improve cardiac function after myocardial infarction in mice without long-term engraftment. Biochem. Biophys. Res. Commun. 2007, 354, 700-706.

106. Prockop, D.J. Repair of tissues by adult stem/progenitor cells (MSCs): controversies, myths, and changing paradigms. Mol. Ther. 2009, 17, 939-946.

107. Lee, T. Host tissue response in stem cell therapy. World J. Stem Cells 2010, 2, 61-66.

108. Sassoli, C.; Pini, A.; Mazzanti, B.; Quercioli, F.; Nistri, S.; Saccardi, R.; Zecchi-Orlandini, S.; Bani, D.; Formigli, L. Mesenchymal stromal cells affect cardiomyocyte growth through juxtacrine Notch-1/Jagged-1 signaling and paracrine mechanisms: Clues for cardiac regeneration. J. Mol. Cell. Cardiol. 2011, 51, 399-408.

109. Sassoli, C.; Pini, A.; Chellini, F.; Mazzanti, B.; Nistri, S.; Nosi, D.; Saccardi, R.; Quercioli, F.; Zecchi-Orlandini, S.; Formigli, L. Bone Marrow Mesenchymal Stromal Cells Stimulate Skeletal Myoblast Proliferation through the Paracrine Release of VEGF. PLoS One 2012, 7, e37512.

110. Shi, C. Recent progress toward understanding the physiological function of bone marrow mesenchymal stem cells. Immunology 2012, 136, 133-138.

111. Tschöpe, C.; Miteva, K.; Schultheiss, H.P.; Linthout, S.V. Mesenchymal stromal cells: A promising cell source for the treatment of inflammatory cardiomyopathy. Curr. Pharm. Des. 2011, 17, 3295-3307.

112. Zanin, M.; Germinario, E.; Dalla Libera, L.; Sandonà, D.; Sabbadini, R.A.; Betto, R.; Danieli-Betto, D. Trophic action of sphingosine 1-phosphate in denervated rat soleus muscle. Am. J. Physiol. Cell. Physiol. 2008, 294, C36-C46.

113. Sassoli, C.; Formigli, L.; Bini, F.; Tani, A.; Squecco, R.; Battistini, C.; Zecchi-Orlandini, S.; Francini, F.; Meacci, E. Effects of S1P on skeletal muscle repair/regeneration during eccentric contraction. J. Cell. Mol. Med. 2011, 15, 2498-2511. 
114. Frey, S.P.; Jansen, H.; Raschke, M.J.; Meffert, R.H.; Ochman, S. VEGF Improves Skeletal Muscle Regeneration After Acute Trauma and Reconstruction of the Limb in a Rabbit Model. Clin. Orthop. Relat. Res. 2012, in press.

115. Gehrig, S.M.; van der Poel, C.; Hoeflich, A.; Naim, T.; Lynch, G.S.; Metzger, F. Therapeutic potential of PEGylated insulin-like growth factor I for skeletal muscle disease evaluated in two murine models of muscular dystrophy. Growth Horm. IGF Res. 2012, 22, 69-75.

116. Urbanek, K.; Rota, M.; Cascapera, S.; Bearzi, C.; Nascimbene, A.; De Angelis, A.; Hosoda, T.; Chimenti, S.; Baker, M.; Limana, F.; et al. Cardiac stem cells possess growth factor-receptor systems that following activation regenerate the infarcted myocardium improving ventricular function and long-term survival. Circ. Res. 2005, 97, 663-667.

117. Bani, D.; Bigazzi, M. Relaxin as a cardiovascular drug: a promise kept. Curr. Drug Saf. 2011, 6, 324-328.

118. Ellison, G.M.; Torella, D.; Dellegrottaglie, S.; Perez-Martinez, C.; Perez de Prado, A.; Vicinanza, C.; Purushothaman, S.; Galuppo, V.; Iaconetti, C.; Waring, C.D.; et al. Endogenous cardiac stem cell activation by insulin-like growth factor-1/hepatocyte growth factor intracoronary injection fosters survival and regeneration of the infarcted pig heart. J. Am. Coll. Cardiol. 2011, 58, 977-986.

119. Nistri, S.; Pini, A.; Sassoli, C.; Squecco, R.; Francini, F.; Formigli, L.; Bani, D. Relaxin promotes growth and maturation of mouse neonatal cardiomyocytes in vitro: clues for cardiac regeneration. J. Cell. Mol. Med. 2012, 16, 507-519.

120. Chen, L.; Tredget, E.E.; Wu, P.Y.; Wu, Y. Paracrine factors of mesenchymal stem cells recruit macrophages and endothelial lineage cells and enhance wound healing. PLoS One 2008, 3, e1886.

121. Németh, K.; Leelahavanichkul, A.; Yuen, P.S.; Mayer, B.; Parmelee, A.; Doi, K.; Robey, P.G.; Leelahavanichkul, K.; Koller, B.H.; Brown, J.M.; et al. Bone marrow stromal cells attenuate sepsis via prostaglandin $\mathrm{E}(2)$-dependent reprogramming of host macrophages to increase their interleukin-10 production. Nat. Med. 2009, 15, 42-49.

122. Ortiz, L.A.; Dutreil, M.; Fattman, C.; Pandey, A.C.; Torres, G.; Go, K.; Phinney, D.G. Interleukin 1 receptor antagonist mediates the antiinflammatory and antifibrotic effect of mesenchymal stem cells during lung injury. Proc. Natl. Acad. Sci. USA 2007, 104, 11002-11007.

123. Uccelli, A.; Moretta, L.; Pistoia, V. Mesenchymal stem cells in health and disease. Nat. Rev. Immunol. 2008, 8, 726-736.

124. Nauta, A.J.; Fibbe, W.E. Immunomodulatory properties of mesenchymal stromal cells. Blood. 2007, 110, 3499-3506.

125. Kortesidis, A.; Zannettino, A.; Isenmann, S.; Shi, S.; Lapidot, T.; Gronthos, S. Stromal-derived factor-1 promotes the growth, survival, and development of human bone marrow stromal stem cells. Blood 2005, 105, 3793-3801.

126. Gnecchi, M.; He, H.; Liang, O.D.; Melo, L.G.; Morello, F.; Mu, H.; Noiseux, N.; Zhang, L.; Pratt, R.E.; Ingwall, J.S.; et al. Paracrine action accounts for marked protection of ischemic heart by Akt-modified mesenchymal stem cells. Nat. Med. 2005, 11, 367-368. 
127. Zhang, M.; Mal, N.; Kiedrowski, M.; Chacko, M.; Askari, A.T.; Popovic, Z.B. SDF-1 expression by mesenchymal stem cells results in trophic support of cardiac myocytes after myocardial infarction. FASEB J. 2007, 21, 3197-3207.

128. Yin, Q.; Jin, P.; Liu, X.; Wei, H.; Lin, X.; Chi, C.; Liu, Y.; Sun, C.; Wei, Y. SDF-1 $\alpha$ inhibits hypoxia and serum deprivation-induced apoptosis in mesenchymal stem cells through PI3K/Akt and ERK1/2 signaling pathways. Mol. Biol. Rep. 2011, 38, 9-16.

129. Kinnaird, T.; Stabile, E.; Burnett, M.S.; Epstein, S.E. Bone-marrow-derived cells for enhancing collateral development: mechanisms, animal data, and initial clinical experiences. Circ. Res. 2004, 95, 354-363.

130. Kinnaird, T.; Stabile, E.; Burnett, M.S.; Lee, C.W.; Barr, S.; Fuchs, S.; Epstein, S.E. Marrow-derived stromal cells express genes encoding a broad spectrum of arteriogenic cytokines and promote in vitro and in vivo arteriogenesis through paracrine mechanisms. Circ. Res. 2004, 94, 678-685.

131. Zhao, W.; Li, J.J.; Cao, D.Y.; Li, X.; Zhang, L.Y.; He, Y.; Yue, S.Q.; Wang, D.S.; Dou, K.F. Intravenous injection of mesenchymal stem cells is effective in treating liver fibrosis. World $J$. Gastroenterol. 2012, 18, 1048-1058.

132. Ohnishi, S.; Sumiyoshi, H.; Kitamura, S.; Nagaya, N. Mesenchymal stem cells attenuate cardiac fibroblast proliferation and collagen synthesis through paracrine actions. FEBS Lett. 2007, 581, 3961-3966.

133. Wynn, T.A. Cellular and molecular mechanisms of fibrosis. J. Pathol. 2008, 214, 199-210.

134. Tang, J.; Wang, J.; Guo, L.; Kong, X.; Yang, J.; Zheng, F.; Zhang, L.; Huang, Y. Mesenchymal stem cells modified with stromal cell-derived factor 1 alpha improve cardiac remodeling via paracrine activation of hepatocyte growth factor in a rat model of myocardial infarction. Mol. Cells 2010, 29, 9-19.

135. Mazhari, R.; Hare, J.M. Mechanisms of action of mesenchymal stem cells in cardiac repair: Potential influences on the cardiac stem cell niche. Nat. Clin. Pract. Cardiovasc. Med. 2007, 4, S21-S26.

136. Hatzistergos, K.E.; Quevedo, H.; Oskouei, B.N.; Hu, Q.; Feigenbaum, G.S.; Margitich, I.S.; Mazhari, R.; Boyle, A.J.; Zambrano, J.P.; Rodriguez, J.E.; et al. Bone marrow mesenchymal stem cells stimulate cardiac stem cell proliferation and differentiation. Circ. Res. 2010, 107, 913-922.

137. Loffredo, F.S.; Steinhauser, M.L.; Gannon, J.; Lee, R.T. Bone marrow-derived cell therapy stimulates endogenous cardiomyocyte progenitors and promotes cardiac repair. Cell Stem Cell 2011, 8, 389-398.

138. Tang, J.M.; Wang, J.N.; Zhang, L.; Zheng, F.; Yang, J.Y.; Kong, X.; Guo, L.Y.; Chen, L.; Huang, Y.Z.; Wan, Y.; et al. VEGF/SDF-1 promotes cardiac stem cell mobilization and myocardial repair in the infarcted heart. Cardiovasc. Res. 2011, 91, 402-411.

139. Formigli, L.; Benvenuti, S.; Mercatelli, R.; Quercioli, F.; Tani, A.; Mirabella, C.; Dama, A.; Saccardi, R.; Mazzanti, B.; Cellai, I.; et al. Dermal matrix scaffold engineered with adult mesenchymal stem cells and platelet-rich plasma as a potential tool for tissue repair and regeneration. J. Tissue Eng. Regen. Med. 2012, 6,125-134. 
140. Giannelli, M.; Chellini, F.; Sassoli, C.; Francini, F.; Pini, A.; Squecco, R.; Nosi, D.; Bani, D.; Zecchi-Orlandini, S.; Formigli, L. Photoactivation of bone marrow mesenchymal stromal cells with diode laser: Effects and mechanisms of action. J. Cell. Physiol. 2012, in press.

141. Guo, Y.H.; He, J.G.; Wu, J.L.; Yang, L.; Zhang, D.S.; Tan, X.Y.; Qi, R.D. Hepatocyte growth factor and granulocyte colony-stimulating factor form a combined neovasculogenic therapy for ischemic cardiomyopathy. Cytotherapy 2008, 10, 857-867.

142. Tang, J.; Wang, J.; Zheng, F.; Kong, X.; Guo, L.; Yang, J.; Zhang, L.; Huang, Y. Combination of chemokine and angiogenic factor genes and mesenchymal stem cells could enhance angiogenesis and improve cardiac function after acute myocardial infarction in rats. Mol. Cell. Biochem. 2010, $339,107-118$.

143. Chen, C.H.; Wei, H.J.; Lin, W.W.; Chiu, I.; Hwang, S.M.; Wang, C.C.; Lee, W.Y.; Chang, Y.; Sung, H.W. Porous tissue grafts sandwiched with multilayered mesenchymal stromal cell sheets induce tissue regeneration for cardiac repair. Cardiovasc. Res. 2008, 80, 88-95.

144. Khait, L.; Hecker, L.; Blan, N.R.; Coyan, G.; Migneco, F.; Huang, Y.C.; Birla, R.K. Getting to the heart of tissue engineering. J. Cardiovasc. Transl. Res. 2008, 1, 71-84.

(C) 2012 by the authors; licensee MDPI, Basel, Switzerland. This article is an open access article distributed under the terms and conditions of the Creative Commons Attribution license (http://creativecommons.org/licenses/by/3.0/). 